\title{
Challenges and Progress in Ensuring the Right to Be Heard and the Best Interests of Children Seeking International Protection
}

\author{
JYOTHI KANICS
}

\section{Abstract}

Societal attitudes towards children significantly limit the extent to which they are able to realize their rights and can contribute to discrimination against children. Fortunately, legislative reform as well as changes in policies and practices are slowly leading to progress for children, in line with the Convention on the Rights of the Child. Child-sensitive procedures for children seeking international protection are being developed and implemented. It is crucial that these systems be strengthened so that durable solutions for children and families are secured without discrimination and in line with the best interests of the children concerned.

\section{Résumé}

Les attitudes d'une société envers les enfants peuvent limiter considérablement leur capacité de faire valoir leurs droits et peuvent contribuer à la discrimination contre les enfants. Toutefois, des initiatives de réforme législative ainsi que des changements en matière de politiques et pratiques sont heureusement en voie d'aboutir à des progrès pour les enfants conformément à la Convention relative aux droits de l'enfant. Des procédés sensibles aux besoins des enfants cherchant la protection internationale sont en processus d'élaboration et de mise en cuvre. Il est essentiel de renforcer ces systèmes afin que des solutions durables pour les enfants et les familles soient assurées sans discrimination et selon l'intérêt supérieur des enfants concernés.

\section{Introduction}

7 he treatment of migrant children and consideration of their claims for international protection in industrialized countries are based on the provisions and implementation of international, regional, and national legal and policy frameworks. In order to understand better the gaps and biases in these frameworks and their application, which may lead to discrimination against children in accessing or receiving international protection, it is helpful to consider the historical attitudes and theoretical approaches towards children and childhood. With changes in society and developments in international human rights law, particularly since the adoption of the Convention on the Rights of the Child (CRC) ${ }^{1}$ in 1989 , it is now recognized that children are endowed with human rights and should be supported to realize those rights. Nevertheless, how do lingering concepts of childhood and family affect the realization of children's rights in practice, particularly for asylum-seeking and at-risk migrant children?

While there has been a great deal of research and advocacy on the situation of separated and unaccompanied migrant children, ${ }^{2}$ there has been far less attention given to the rights and protection of children migrating with their families. Accompanied migrant children are often viewed simply as appendages, rather than as separate individuals, who have rights and who may have international protection needs, perhaps even a stronger claim than that of their parents. According to the guiding principles and related obligations set out in the CRC, states should allow each child to express his or her views and to take that into account when considering the best interests of the child without 
discrimination and with a view to ensuring the child's right to life, survival, and development. Yet while there is international law and guidelines, few states assess the cases of accompanied migrant children systematically in international protection procedures.

There is a continuing evolution of law in this field at the international, regional, and national levels. Furthermore, states have been pushed to make progress in practice based on recent jurisprudence, auditing of practice, and authoritative guidance from the Committee on the Rights of the Child, UNHCR, and others. Fortunately, some new policies and practices are emerging that seek to operationalize the best-interests principle and to ensure respect for the rights of all migrant children. Child-sensitive and child-friendly international protection procedures-for both unaccompanied and accompanied children, whether asylum-seeking or irregular-are being established and implemented. ${ }^{3}$ It is crucial that these systems be strengthened so that outcomes for children and families are secured without discrimination and in line with the best interests of the children concerned. Such "durable solutions" would ensure that the children are able to develop into adulthood, in an environment that will meet their needs and fulfil their rights as defined by the CRC and will not put children at risk of persecution or serious harm. 4

\section{Children: Our Most Cherished Possession?}

According to Article 1 CRC, a child is defined as "every human being below the age of eighteen years unless under the law applicable to the child, majority is attained earlier." Despite this legal marker of the age of majority, it is important to bear in mind other social constructs of age that may lead to different understandings of roles and capacities as well as the reality where vulnerability may have no age limit.5 In assessing the impact of the CRC, Save the Children expressed concern that children's needs are often subsumed within a family agenda and criticized the traditional approach that leaves children with "no voice and no power within families." 6

It is not surprising, therefore, that law and jurisprudence often tend to reflect "confused" societal constructs of age, family relations, and attitudes towards children.7 Our societal view and perception of children and childhood significantly limit the extent to which children are able to realize their rights, and can contribute to discrimination against children. As Thronson and others have emphasized, "Deeply ingrained ideas about children's rights, often unacknowledged and unexamined, shape the way children are perceived and treated." 8

Discrimination against children is in part a result of historical attitudes that view children either as controlled or protected by their parents. Such attitudes stem from the time when children were viewed as "assets" to be controlled or as "wards" to be protected. 9 While this latter approach, focused on the child's welfare, may give rise to special treatment and protection, it does not signify a true appreciation of the rights of the child. Smyth also highlights this "theory gap" and philosophical criticism of child rights as contributing to the "residual ambiguity in law, policy and practice about the status of the child as rights-bearer." ${ }^{\circ}$ As will be described below, this ambiguity leads to the neglect of children's rights in law and in practice. Smyth rightly stresses that it is important to be aware of this gap because it persists today and continues to inform the legal and policy framework. Therefore, it also limits the outcomes that are possible for children. On the one side of this moral theory debate are those who argue that children lack autonomy and rights and, thus, require protection and child welfare measures. On the other side, liberationists consider children as autonomous rights-holders, even if they may lack capacity to exercise their rights autonomously. ${ }^{11}$ Children may require special assistance and supports in order to participate meaningfully in matters that may affect them. Yet a certain age does not necessarily equate to specific level of capacity or correlate with competency. ${ }^{12}$ Moreover, even those children who can demonstrate maturity and competency may still need assistance, such as the support of a guardian ad litem in court proceedings, because as children they usually lack legal capacity.

In order to explain why immigration law does not fully recognize children as individuals with independent rights and interests, Thronson argues that debates about children's rights have largely bypassed immigration law. ${ }^{13}$ Similarly, Bhabha asserts that the "notorious invisibility of children in international law applies to refugee law in particularchildren have simply not been thought of as appropriate subjects of asylum applications or refugee status grants." 14 She further claims that migration authorities and children's rights experts are separated in silos and that this isolation has militated against the development of a child-specific refugee law regime. ${ }^{15}$ This divergent approach can also be seen in domestic legal frameworks where child protection legislation and immigration and asylum law do not accord with each other. This also means that migration authorities rarely request or consider the opinions of child protection professionals, who are working directly with the children concerned, even when children have been placed in the care of national child-protection systems, as is the case in many European countries. ${ }^{16}$

Furthermore, decision-makers in the immigration and asylum system do not take the child's perspective into consideration, because "children are not expected to have a 
role or meaningful contribution." 17 Unfortunately, it is not only decision-makers whose attitudes limit the realization of children's rights, but even advocates and parents may not perceive the need to listen to the voices of children or may try to shield them from the asylum process, which is frequently viewed as traumatizing. ${ }^{18}$ According to good practice standards, however, an individual assessment should be made whether it is in the child's best interests to be interviewed. Ironically, measures created to protect a child may mean that the child's story is not heard and that the child does not receive a more durable solution to his or her protection needs. For example, Lundberg found that handling officers at the Swedish Migration Board, who were afraid of re-traumatizing children, avoided talking to children and consequently failed to give due weight to the best interests of the child. ${ }^{19}$ In this regard, models from the child protection field, such as the Barnahus or Children's House model, could provide inspiration for less adversarial and more child-sensitive asylum and immigration procedures. Thus far in immigration and asylum matters, it has proven difficult for families and authorities alike to recognize the potential vulnerability and special needs of children, while at the same time respecting their rights and entitlements.

\section{From Child Welfare to Child Rights: A More Holistic Approach}

Yet the CRC does exactly that: it acknowledges not only the special needs and vulnerability of children along with their entitlement to protection, but also recognizes their agency and right to participate. While theoretical debates continue, the adoption of the CRC in 1989, followed by its near-universal ratification, have strengthened our understanding of and the realization of children's rights around the world. From a positive law point of view, there is no longer any debate-children have a variety of non-derogable rights as prescribed in the CRC.

States have demonstrated a real commitment to children's rights and made progress in this field through the "General Measures of Implementation" of the CRC, as outlined in General Comment No. 5 from the Committee on the Rights of the Child. Such measures include legislative reform and removal of reservations to the CRC. In several countries, constitutional reform has enshrined children's rights in the national legal framework. ${ }^{20}$ At the same time, additional legislative amendments have resulted in elements of the CRC being incorporated directly into specific national legislation concerning immigration and child protection. ${ }^{21}$ Notably, a significant number of reservations and declarations to the CRC have been withdrawn. ${ }^{22}$ For example, in 2008, as recommended by all of the UK children's commissioners and the UK Parliament's Joint Committee on Human Rights, the UK government withdrew its reservation to CRC Article 22, which means that all children in the United Kingdom are now entitled equally to the protections afforded by the CRC, regardless of their immigration status. ${ }^{23}$ Likewise, Germany also recently withdrew its reservation on Article 22.

With regards to national enforcement of the $\mathrm{CRC}$, while there are different legal traditions across Europe, some national courts have recognized the CRC as a binding obligation in international law that should guide national and European jurisprudence concerning children. ${ }^{24}$ Notably, courts in Europe, Canada, Australia, and New Zealand have specifically considered the best interests of the child in cases related to immigration and international protection, including cases involving the potential deportation or extradition of a parent. ${ }^{25}$ However, it should be noted that at the same time there may be a divergence of interpretation of the different articles of the CRC, even within a single country. ${ }^{26}$ Additionally, inconsistency of approaches and divergence in the commitment to the CRC has been noted, in particular in federal states. ${ }^{27}$ Seeking to address these challenges of application and legal interpretation, the Committee on the Rights of the Child clarifies obligations towards children and provides authoritative guidance on the implementation of the CRC in its General Comments and in its Concluding Observations and Recommendations to State Parties.

\section{Children Seeking and Deserving International Protection}

Today states are responsible for ensuring all rights provided for in the CRC to all children, including children attempting to enter their territory. ${ }^{28}$ Even before the adoption of the CRC, children affected by armed conflict were recognized as a group deserving protection. ${ }^{29}$ UNHCR's policies and programming concerning children have also evolved over the past decades, since it issued its first Guidelines on Refugee Children in August 1988.30

More recently, with regards to the challenges that children face in applying for asylum, the 2009 UNHCR Guidelines on Child Asylum Claims begin by acknowledging,

The specific circumstances facing child asylum-seekers as individuals with independent claims to refugee status are not generally well understood. Children may be perceived as part of a family unit rather than as individuals with their own rights and interests. This is explained partly by the subordinate roles, positions and status children still hold in many societies worldwide. The accounts of children are more likely to be examined individually when the children are unaccompanied than when they are accompanied by their families. Even so, their unique experiences of persecution, due to factors such as their age, their level of maturity and development and their dependency on adults have not always been taken into account. Children may not be able to articulate 
their claims to refugee status in the same way as adults and, therefore, may require special assistance to do so. ${ }^{11}$

This is true for both unaccompanied children and children with their families. Yet, unfortunately, accompanied children rarely receive any attention or special assistance in this regard.

The number of children affected by conflict and seeking asylum has grown significantly in recent years. According to UNHCR, more than half of the world's refugees are now children..$^{32}$ The number of unaccompanied asylum-seeking children in the EU has increased from 2010 onwards and nearly doubled from 2013 to reach more than 23,100 in 2014 . In 2015, 98,400 unaccompanied children applied for asylum in seventy-eight countries. 33 Sweden alone received applications from 35,369 unaccompanied asylum-seeking children and 70,385 children in families in $2015 .{ }^{34}$

Children may be seeking asylum because they have been subjected to or fear being subjected to persecution. UNHCR's Guidelines on Child Asylum Claims describe how a well-founded fear of persecution may include violations of child-specific rights, child-specific forms of persecution, and child-related manifestations of persecution where children may not experience harm in the same way as adults. 35 Child-specific forms of persecution include, but are not limited to, under-age recruitment, child trafficking, female genital mutilation, family and domestic violence, forced or underage marriage, bonded or hazardous child labour, forced prostitution, and child pornography. ${ }^{36}$ Despite the fact that child-specific persecution is enshrined in EU legislation 37 and has been transposed into national legislation throughout Europe, only a handful of countries have adopted guidelines to assist decision-makers in assessing protection claims from children. ${ }^{38}$

Specifically regarding persecution on political grounds, Bhabha highlighted how the paucity of child-specific country-of-origin information has "obscured the extent to which children are both active political agents and victims of persecutory acts." 39 Smyth has also described how children are perceived as not having a civil and political status, in part as the result of the Western idealized conception of childhood where children are apolitical and unburdened by "adult" concerns. ${ }^{\circ 0}$ Yet she debunks this antiquated notion when she points out that at least twenty-one provisions of the CRC enshrine civil and political rights. ${ }^{41}$ The UNHCR guidelines also emphasize that "it is important to acknowledge that children can be politically active and hold particular political opinions independently of adults and for which they may fear being persecuted." 42

It has been well documented that children flee from persecution, conflict, poverty and violence. Still, unfortunately, there is also evidence to support the claim that "the harshest reality for the child refugee often comes after the fact of flight." 43

\section{Separated and Unaccompanied Children}

As pointed out by Bhabha and Young, a historical shortcoming of asylum law is that it has failed to acknowledge the unique needs of children seeking refuge from human rights violations, and has required that they meet the same procedural, evidentiary, and legal rules as have been applied to adult asylum-seekers. ${ }^{44}$ Thronson has also commented that this "unthinking abandonment of children to adult status serves to silence children by not providing them with the means to assure that their voices are heard." 45 Over the past two decades, such treatment has improved for unaccompanied and separated children in many countries in Europe, following research ${ }^{46}$ and advocacy efforts, which led to changes to the Eu legal framework, national legislation, and practice.

Still, despite the efforts outlined in the EU Action Plan on Unaccompanied Minors 47 and implemented by EU agencies-including training modules on interviewing children by the Europe Asylum Support Office and a handbook on guardianship by EU FRA-there is still a need for more legislative reform and better practice within Europe. One indication of the apparent gap in protection is the insufficient and temporary outcomes, which many separated and unaccompanied children have to endure. Even separated children who receive assistance to make their claim are much less likely to receive refugee status than their adult counterparts or to have child-specific forms of persecution recognized. $4^{8}$ Many children are left with a temporary status that does not respect their best interests or secure their long-term stability and development. Perhaps this is also linked with the "traditional welfare-based approach" noted in the UNHCR handbook and other policy documents that do not give enough significance to the child's agency and right to participate in the asylum procedure, which may lead to unsatisfactory outcomes. ${ }^{49}$ In addition, many countries apply temporary non-harmonized protection status $5^{50}$ specifically for unaccompanied children, which have been criticized as not being in the best interests of the child, since they do not provide a durable solution and can cause great anxiety for the child..$^{51}$

Worryingly, a study by the Council of Europe and UNHCR found that separated and unaccompanied children who reach the age of majority before the final determination of their asylum claim lose a series of specific guarantees, which may affect their ability to argue their case and therefore the outcome of the procedure..$^{2}$ The key safeguards to which children are entitled should be extended to youth turning 
eighteen, when deemed appropriate, so as not to undermine the submission and the examination of the child's claim for international protection. 53

Even more disturbing, in a recent European Migration Network study on unaccompanied children, nine countries reported that the situation upon turning eighteen changes drastically for non-asylum-seeking children and those whose application for protection was rejected. Upon turning eighteen, they may be "found to be illegally present" and forcibly returned to their country of origin..$^{54}$ It appears that this also leads to more disappearances of children before they age out and a high risk of exploitation.

\section{Accompanied Children}

While there are still gaps in protection to be addressed for age-disputed individuals, those who age out, and those who receive a form of temporary protection, in general there have been improvements for separated and unaccompanied children in Europe in recent years. In contrast, children migrating with their families still remain unseen and their stories untold. Research and advocacy regarding the situation and treatment of accompanied children is sorely lacking in most countries. 55 What research does exist shows that children migrating with their families are not necessarily safe from harm. ${ }^{56}$ While family ideally provides a protective environment, this is not always the case. Family may also mean dependency, which often exposes accompanied children to the harsher aspects of immigration control, including detention and forced repatriation, usually without separate legal aid or representation. 57 Indeed, when one tries to examine the situation of detention and forced removal of migrant families, there is a lack of data, lack of transparency, and real concern for the treatment of children involved, which may indeed amount to human rights violations at the hands of the state. ${ }^{8}$

When seeking asylum, most accompanied children tend to be subsumed within their family's asylum application and therefore remain invisible.59 Indeed, the UNHCR handbook recommends that children accompanied by a parent have their cases determined in accordance with the principle of family unity. ${ }^{60}$ Therefore, often for accompanied children, no individualized determination procedure is normally envisaged. ${ }^{61}$ Indeed, the UNHCR handbook has remained relatively silent on this point, stating simply that "if the head of family is not a refugee, there is nothing to prevent any one of his dependents, if they can invoke reasons on their own account, from applying for recognition as refugees under the 1951 Convention or the 1967 Protocol." 62 Yet accompanied children do indeed face barriers in accessing international protection. ${ }^{63}$ Not only should nothing prevent accompanied children from exercising their right to seek asylum, but they should also be entitled to it in law and enabled to access it with the support of child-sensitive procedural safeguards.

Additionally, Goodwin-Gill rightly critiques the UNHCR handbook for invoking "mental development and maturity" as the criterion for determining a "well-founded fear" of persecution. ${ }^{64} \mathrm{He}$ contends that the handbook is misguided in that there is no necessary connection between maturity and well-founded fear: children are as capable as adults of feeling fear; the child's maturity is irrelevant to the question of whether he or she will be persecuted; and, finally, the best interests of the child should be taken as a primary consideration. ${ }^{65}$ Unfortunately, this has not been addressed in revisions of the handbook. However, in 2009 UNHCR issued its Guidelines on Child Asylum Claims, which complement the handbook and address some of its shortcomings. Certainly, if these guidelines were translated into national guidelines, training materials, and tools, they would support progress towards more child-sensitive protection procedures.

Still, even after UNHCR issued its Guidelines on Child Asylum Claims, Bhabha found that for separated and unaccompanied children, being a child reduces the chances of obtaining refugee status, but also reduces the risk of refoulement or return. ${ }^{66}$ For accompanied children, this protection against refoulement or return is the exception rather than the norm.

Recent studies by UNICEF and UNHCR highlight European states' disregard for the rights of accompanied asylum-seeking children. UNICEF Germany's study shows how accompanied asylum-seeking children are treated as appendages to their parents rather than as individual rights-holders with child-specific needs. ${ }^{67}$ UNICEF Germany found that there is a disregard for the best interests of the child as well as a discrimination in comparison to other children. ${ }^{68}$ Accompanied children in Germany are rarely heard in international protection procedures. ${ }^{69}$ Notably, the best interests of the child have not been considered before families are returned..$^{\circ}$

As part of its Quality Integration project, UNHCR UK reviewed the quality of asylum decisions for families seeking international protection in the United Kingdom. The study found good practice as well as shortcomings. Most notably, regarding access to the procedure and identification of claims, it was found that "children being considered for derivative status do not have adequate opportunity to participate and to provide evidence during the asylum process." 71 The audit found no evidence of accompanied asylum-seeking children being heard independently of family members. ${ }^{72}$ It was also found that screening measures could be strengthened ${ }^{73}$ as well as decision-making better informed through the use of child-specific country-of-origin information. ${ }^{74}$

A second UNHCR UK report based on the audit findings examines how the best interests of children are considered 
throughout the asylum procedure in the United Kingdom. That audit found that there is a "lack of any mechanism to obtain the views of the child and give those views weight in line with age and maturity." 75 As noted in General Comments No. 12 and No. 14 from the Committee on the Rights of the Child, the child's right to be heard and the best interests of the child are inextricably linked. Indeed, the committee stresses that "there can be no correct application of article 3 if the components of article 12 are not respected." 76 In this light, UNHCR is "concerned that the findings of an absence of the participation of children within a family unit in the asylum process impacts upon the UK's ability to assess the child's best interests." 77 The findings found that not all accompanied children are having their best interests determined and, if they are, the best interests are not considered fully and appropriately. ${ }^{78}$ Alarmingly, the UNHCR audit found that "care, protection and safety of the child were rarely considered when determining the best interests."79 While the element of immigration control or other state interests should not be brought into the analysis of the best interests, ${ }^{80}$ UNHCR found that it was included directly in a quarter of the claims audited. In summary, decision-makers are unclear when and how to consider the best interests of the child, even though it is required by law and policy. ${ }^{81}$

It has been recognized that other EU member states' policies and practices also tend to focus on the parents and that the best interests of children are not taken into consideration in a structural and explicitly motivated way-neither in asylum procedures nor in return decisions. ${ }^{82}$ Therefore, targeted projects have created tools for monitoring and evaluating the outcomes for children and families, who have been returned, with the aim of providing insight into the effects of current policies and generating new opportunities for improvement such as the application of the Best Interests of the Child Model in the Netherlands that will be examined below.

Unfortunately, the United States is another case where children's rights and best interests are most often neglected in the asylum and immigration systems. Accompanied children in the United States are "at risk of serious harm, including persecution and torture, because of their invisibility and lack of access to protection." 83 UNHCR has just initiated a study that aims to shine a light on procedural gaps that jeopardize access to protection for accompanied children in the United States, as well as examples that demonstrate good practices in promoting accompanied children's access to protection.

\section{Emerging Good Practice: Child-Sensitive International Protection Procedures}

Twenty years ago, Guy Goodwin-Gill wrote, "The CRC uniquely embraces the whole spectrum of children's rights, specifically endorsing the principle of the best interests of the child in a total regime oriented to his or her development and self-fulfilment. Today, the child is subject, not object. International law and international instruments do not alone provide the answers, although the CRC can be used as a model of the achievable, somewhat in the sense of a checklist: a review of its provisions expands the concept of protection, while encouraging focus on the possibilities for effective implementation in any situation of forced migration." 84

Unfortunately, decades later, much remains to be improved in law, policy, and practice to "expand the concept of protection" for both unaccompanied and accompanied children seeking asylum or facing removal. For unaccompanied and separated children, the Committee on the Rights of the Child reaffirmed that the ultimate aim in addressing their fate "is to identify a durable solution that addresses all their protection needs, takes into account the child's view and, wherever possible, leads to overcoming the situation of a child being unaccompanied or separated." 85 According to UNICEF and UNHCR, a durable solution is a sustainable solution that ensures that the unaccompanied or separated child is able to develop into adulthood, in an environment that will meet his or her needs and fulfil his or her rights as defined by the CRC and will not put the child at risk of persecution or serious harm. ${ }^{86}$ UNHCR and UNICEF have captured good-practice examples and outlined what states can do to ensure respect for the best interests of unaccompanied and separated children in Europe in their recent publication Safe \& Sound. The publication builds on CRC General Comment No. 14 outlining which elements should be considered and weighed in a Best Interests Determination and how to balance the interests of the child against competing interests that are rights based.

Interestingly, in Europe and North America, Best Interests Determinations have in some countries first been developed as part of special measures for trafficked children in order to operationalize the best-interests principle from the law. For example, the Eu Trafficking Directive requires that a durable solution is found for child victims of trafficking, whether that child is accompanied or unaccompanied and separated. In either case, a durable solution is one that seeks to provide a long-term and sustainable solution for the child based on an individual assessment of the best interests of the child, including taking due account of the child's views, needs, and concerns. ${ }^{87}$ The Council of Europe Convention on Action against Trafficking in Human Beings also requires respect for the best interests of the child, including in decisions concerning the grant of a residence permit. ${ }^{88}$ While the best interests standard is mainly absent from U.S. immigration law, noteworthy practice has developed under 
the 2008 Trafficking Victims Protection Reauthorization Act, which allows for the appointment of independent child advocates to unaccompanied children. The independent child advocate's role is to identify and advocate for the best interests of the child, and the Young Centre for Immigrant Children's Rights has developed a paradigm for such assessments based in part on guidance in CRC General Comments. ${ }^{89}$ Recommendations from a Best Interests Determination Panel are then discussed during immigration court proceedings and considered by the judge deciding the case. Drawing upon this practice as well as experiences with the Special Immigrant Juvenile Status, U.S. practitioners are advocating for the application of the best-interests standard in other immigration contexts, such as in immigration deportation proceedings.

Respecting the best interests of the child requires both procedural and substantive measures. ${ }^{90}$ Procedural safeguards, such as the appointment of a guardian and provision of legal aid, ensure that the child's voice is heard, while substantive decision-making should prioritize safety, permanency, and well-being. ${ }^{91}$ McAdam and others have noted that states initially applied the best-interests principle in procedural aspects for unaccompanied children and that consideration of the best interests in the substantive determination of refugee status was "widely overlooked."92 This is still likely to be the case, but practice and jurisprudence are slowly evolving following recent guidance from the Committee on the Rights of the Child and UNHCR, as well as legislative and case law developments at the Eu level. Many states, such as Finland, Norway, and Sweden, have included the best-interests principle in legislation and policies concerning asylum-seeking and migrant children. ${ }^{93}$ At the same time, the best interests of the child are increasingly being considered by the courts as well. 94

The Separated Children in Europe Programme, including Save the Children, UNHCR, UNICEF, and many partners, have elaborated The Statement of Good Practice and advocated for better reception, care, and treatment of separated and unaccompanied children. ${ }^{95}$ Arguably, the majority of these measures, which reflect CRC obligations and UNHCR guidance, are also relevant for accompanied children. A comprehensive review of the key elements of a child-sensitive international protection procedure is beyond the scope of this article, but a few key elements will be outlined below. Many recent publications and projects could be drawn upon for in-depth analysis. In particular, Smyth provides a detailed review of whether and how the Common European Asylum System complies with the rights of the child. ${ }^{96}$ Additionally, Save the Children produced a Reference Document on EU Law and Policy ${ }^{97}$ concerning unaccompanied children as part of its CONNECT project, which includes tables mapping how different articles of the CRC are reflected in EU law and policy. This mapping tool could also be used to analyze provisions from national legislation.

Equal rights and protection for accompanied children seeking international protection should be enshrined in legislation and policy at the EU and national level. For example, children's right to have access to the asylum procedure should be guaranteed in law. In its 2010 study on improving asylum procedures, UNHCR noted, "In order to address the absence of national legislation and administrative instructions in some Member States, the Asylum Procedures Directive should require Member States to determine in law the circumstances in which children shall be given the opportunity of a personal interview and/or the right to be heard." 98 Unfortunately, this is still not required by the recast directive.

Concerning the right to participation and the right to be heard, the Committee on the Rights of the Child discourages states from introducing standardized age limits in law or policy. ${ }^{99}$ In this regard, UNHCR's emphasis on the use of appropriate communication methods and non-verbal means of communication is welcomed. ${ }^{100}$

Regarding interviewing and decision-making, the Swedish practice provides inspiration in law, policy, and practice. Section 10 of the Swedish Alien's Law specifically states, "In cases involving a child, particular attention must be given to what is required with regard to the child's health and development and the best interests of the child in general." The subsequent regulation ${ }^{101}$ requires the Swedish Migration Board to analyze the consequences for the child before making decisions or other actions concerning the child. Such a child-rights impact assessment is a method to take into consideration the best interests of the child as explained in General Comment No. 14 of the Committee on the Rights of the Child. The Swedish Migration Board has produced and uses checklists in its work with children to ensure a basis for the child-rights impact assessment as well as Best Interests Assessments throughout the process. The reasoning of the decision must also be documented and the must child be informed. For such measures to be effective, all professionals interacting with children should receive specialized training and guidance. Interview protocols and checklists can be helpful tools to apply principles into practice. A specific checklist has been developed in Sweden for work with children in families. Child-specific country-oforigin information should also be taken into count by the Swedish Migration authorities. UNICEF has been working with UNHCR and partners to further develop a methodology for "Child Notices,"102 child-focused country-of-origin reports that provide reliable information about child rights and child protection. 
The Norwegian authorities have also reformed their laws and policies and have interviewed accompanied children over the age of twelve since $2005 .{ }^{103}$ A 2006 government circular outlines the principles for the interview or "conversation" with accompanied children and lowered the interviewee age to seven, in line with other Norwegian legislative provisions related to the child's right to be heard. Importantly, immigration authorities "stress that the conversation should not check the accounts given by parents, nor include information from the child conversation in the proceedings which could undermine the family's case."104 This crucial safeguard should also find its way into policy and practice. Otherwise, as noted in Lundberg's study in Sweden, the authorities may be afraid of getting the child to talk about something that contradicts what the parents had said in earlier interviews, and this could become a barrier in practice to interviewing children. ${ }^{105}$

In 2014, UNHCR published The Heart of the Matter: Assessing Credibility when Children Apply for Asylum in the European Union. ${ }^{106}$ While the study focuses on cases involving unaccompanied children in Europe, the learnings and recommendations are relevant also for the treatment of other children applying for international protection. In particular, states could improve decision-making by applying credibility indicators in a child-sensitive manner and recognizing a shared and flexible burden of proof.

Finally, it remains a challenge to gather evidence and to consider children's claims in a multidisciplinary way. In the Dutch experience, Kalverboer and her colleagues have developed a robust methodology called the Best Interests of the Child Model, which assesses " 14 rearing conditions in a child's life, which must be of sufficiently high quality to enable the child to experience a good childhood and to safeguard his or her development."107 Using a questionnaire to assess these conditions in the child's current environment as well as to compare it with possible alternative future options for the child, the University of Groningen has submitted hundreds of child-oriented social welfare reports to the Dutch immigration authorities and to district courts, who are deciding on the fate of the children concerned. Such detailed analysis assists decision-makers to consider fully the best interests of the child.

\section{Conclusion}

In its 2007 Conclusion No. 107 on Children at Risk, UNHCR's Executive Committee recommended that States, UNHCR and other relevant agencies and partners work: "Within the framework of the respective child protection systems of States, utilize appropriate procedures for the determination of the child's best interests which facilitate adequate child participation without discrimination: where the views of the child are given due weight in accordance with age and maturity; where decision makers with relevant areas of expertise are involved; and where there is a balancing of all relevant factors in order to assess the best option."108

In Europe, more than a third of EU member states report that a Best Interests Determination is in place to support the competent authority's decision on a durable solution for a separated or unaccompanied child. ${ }^{109}$ Most likely these procedures will still need to be improved, but states' recognition of that they have a responsibility to consider the best interests of the child in such circumstances is an important step towards operationalizing the principle into practice. Forthcoming research will assess these emerging practices against good-practice standards and the CRC, as well as examine the outcomes for children and families concerned. As described above, more child rights advocates are coming forward to lobby for a Best Interests Determination to be carried out when deciding on durable solutions for children and their families, who no longer qualify for international protection or who are living in an irregular situation.

Clearly, there is a lot of work ahead in order to make such a reality viable. First, child rights education can empower children, raise awareness of children's rights, and change attitudes among policy- and decision-makers with the aim of improving law, policy, and practice. The use of the CRC to inform law and policy should continue to be strengthened, including child rights informing decisions on international protection and the CRC being considered as an independent source of status. ${ }^{110}$ As McAdam argues, the CRC should be used as the key deciding factor when assessing whether a child needs international protection. ${ }^{111}$

Finally, national human rights institutions and ombudspersons for children can play a significant role in monitoring the treatment of migrant children in their countries. ${ }^{112}$ Quality audits that examine the treatment of family claims and children's claims can provide valuable evidence from which to formulate policy recommendations to improve national systems. The analysis of anonymized decisions can also inform the understanding of the interpretation and implementation of key legal provisions and principles such as the best interests of the child.

UNHCR's 1993 Policy on Refugee Children called on staff to integrate children into the protection and programming processes, explaining that "they are people in their own right, with suggestions, opinions and abilities to participate in decisions and activities that affect their lives. Efforts on behalf of refugee children fall short if they are perceived only as individuals to be fed, immunized or sheltered, rather than treated as participating members of their community."113

No doubt these words were meant for staff working in developing countries or in an emergency, but this policy 
advice also holds true for industrialized countries. In line with Article 12 of the CRC, authorities should also consult with children for feedback on their experiences with the asylum and immigration systems and use their advice to change the system for the better. ${ }^{114}$

\section{Notes}

1 Convention on the Rights of the Child, New York, 20 November 1989, United Nations Treaty Series, vol. 1577, 3.

2 See, for example, the research and guidelines, "Suggested Background Material for 2016 Dialogue on Children on the Move," http://www.unhcr.org/events/ conferences/581c888d4/suggested-background-material2016-dialogue-children-move.html.

3 Such child-sensitive procedures are based on guidelines such as the Council of Europe Guidelines for ChildFriendly Justice and UNHCR's Guidelines on Child Asylum Claims.

4 UNHCR and UnICEF, Safe and Sound: What States Can Do to Ensure Respect for the Best Interests of Unaccompanied and Separated Children in Europe (Brussels: UNHCR, 2014), 22.

5 Christina Clark-Kazak, "Towards a Working Definition and Application of Social Age in International Development Studies," Journal of Development Studies 45, no. 8 (2008): 1-18; UNHCR, Guidelines on International Protection No. 8: Child Asylum Claims under Articles 1(A)2 and $1(F)$ of the 1951 Convention and/or 1967 Protocol relating to the Status of Refugees, 22 December 2009, HCR/GIP/o9/o8, http://www.refworld.org/docid/4b2f 4 f6d2.html, para 7 .

6 Save the Children, Children's Rights: A Second Chance (London: International Save the Children Alliance, 2001), 62.

7 Janet L. Dolgin, "The Age of Autonomy: Legal Reconceptualizations of Childhood," Quinnipiac Law Review 18 (1999): 421-50.

8 David B. Thronson, "Kids Will Be Kids? Reconsidering Conceptions of Children's Rights Underlying Immigration Law," Ohio State Law Journal 63 (2002): 980.

9 Ibid., 979-1016.

10 Ciara Smyth, European Asylum Law and the Rights of the Child (Oxon, uk: Routledge, 2014), 31.

11 David William Archard, "Children's Rights," Stanford Encyclopedia of Philosophy (Winter 2014), http://plato .stanford.edu/archives/win2014/entries/rights-children/.

12 Gerison Lansdown, The Evolving Capacities of the Child (Florence: UNICEF Innocenti Research Centre, 2005).

13 Thronson, "Kids Will Be Kids?," 980.

14 Jacqueline Bhabha, "More Than Their Share of Sorrows: International Migration Law and the Rights of Children," Immigration and Nationality Law Review 24 (2003): 314.

15 Ibid., 315.

16 Greater Manchester Immigration Aid Unit, Child's Best Interests: A Primary Consideration? (Manchester: Greater Manchester Immigration Aid Unit, 2013).
17 Thronson, "Kids Will Be Kids?," 997.

18 Ibid.; Hilde Liden and Hilde Rusten, "Asylum, Participation and the Best Interests of the Child: New Lessons from Norway," Children and Society 21 (2007): 273-83.

19 Anna Lundberg, "The Best Interests of the Child Principle in Swedish Asylum Cases: The Marginalization of Children's Rights," Journal of Human Rights Practice 3, no. 1 (2011): 49-70.

20 UNICEF, Law Reform and Implementation of the Convention on the Rights of the Child (Florence: UNICEF Innocenti Research Centre, 2007), 13-16.

21 UNICEF and OHCHR, Judicial Implementation of Article 3 of the Convention on the Rights of the Child in Europe (Brussels: OHCHR, 2012), 23.

22 UNICEF, Law Reform, 9.

23 For an update on recent progress in the UK since the removal of the reservation and further recommendations for improvements, see UNHCR and UNICEF UK, What the United Kingdom Can Do to Ensure Respect for the Best Interests of Unaccompanied and Separated Children, http:// www.unhcr.org/5756e8co7.pdf.

24 UNICEF and OHCHR, Judicial Implementation of Article 3, 13. 25 Ibid.; Jason M. Pobjoy, "The Best Interests of the Child Principle as an Independent Source of International Protection," International and Comparative Law Quarterly 64 , no. 2 (2015): 327-63.

26 UNICEF and OHCHR, Judicial Implementation of Article 3, 23.

27 Geraldine Sadoway, "Canada's Treatment of Separated Refugee Children," European Journal of Migration and Law 3 (2001): 347-81; UNICEF UK and Queen's University Belfast, The UN Convention on the Rights of the Child: A Study of Legal Implementation in 12 Countries (London: UNICEF UK, 2012), 4-5; Canadian Coalition for the Rights of the Child, Right in Principle, Right in Practice: Implementation of the Convention on the Rights of the Child in Canada (Canada: Canadian Coalition for the Rights of the Child, 2011); Daja Wenke, Vulnerable Children in Switzerland: Safeguarding the Rights of Every Child (Zurich: UNICEF Switzerland, 2010).

28 Committee on the Rights of the Child, General Comment No. 6 (2005): Treatment of Unaccompanied and Separated Children Outside Their Country of Origin, 1 September 2005, CRC/GC/2005/6, http://www.refworld.org/ docid/42dd174b4.html.

29 Guy Goodwin-Gill, "Unaccompanied Refugee Minors: The Role and Place of International Law in the Pursuit of Durable Solutions," International Journal of Children's Rights 3 (1995): 405-16.

30 UNHCR, "Report on Refugee Children," Refugee Survey Quarterly 15, no. 3 (1996): 59-73; UNHCR, "Policy on Refugee Children," Refugee Survey Quarterly 15, no. 3 (1996): 48-56; Jeff Crisp, "Meeting the Needs and Realizing the Rights of Refugee Children and Adolescents: From Policy to Practice," Refugee Survey Quarterly 15, no. 3 (1996): 1-24; 
Jason M. Pobjoy, "A Child Rights Framework for Assessing the Status of Refugee Children," in Contemporary Issues in Refugee Law, ed. Satvinder Singh Juss and Colin Harvey, 91-138 (Cheltenham, UK: Edward Elgar, 2013) .

31 UNHCR, Guidelines on Child Asylum Claims.

32 UNHCR, Global Trends in Forced Displacement 2015.

33 Ibid.

34 Swedish Migration Board statistics, http://www.migrationsverket.se/English/About-the-Migration-Agency/ Facts-and-statistics-/Statistics.html.

35 UNHCR, Guidelines on Child Asylum Claims.

36 Ibid., para. 18.

37 See article 9 of the EU Qualification Directive, Directive 2011/95/EU of the European Parliament and of the Council of 13 December 2011 on standards for the qualification of third-country nationals or stateless persons as beneficiaries of international protection, for a uniform status for refugees or for persons eligible for subsidiary protection, and for the content of the protection granted.

38 Mailis Reps. Doc. 12539, Unaccompanied Children in Europe: Issues of Arrival, Stay and Return (Strasbourg: Committee on Migration, Refugees and Population, Parliamentary Assembly of the Council of Europe, 2011), paras. 66-7.

39 Bhabha, "More Than Their Share of Sorrows," 267.

40 Smyth, European Asylum Law, 66.

41 Ibid., 66-70.

42 UNHCR, Guidelines on Child Asylum Claims, para. 45.

43 Goodwin-Gill, "Unaccompanied Refugee Minors," 412.

44 Jacqueline Bhabha and Wendy Young, "Not Adults in Miniature: Unaccompanied Child Asylum-seekers and the New U.S. Guidelines," International Journal of Refugee Law 11, no. 1 (1999): 84-125.

45 Thronson, "Kids Will Be Kids?, 1002.

46 Fundamental Rights Agency of the European Union, Separated, Asylum-Seeking Children in European Union Member States: Comparative Report (Vienna: EU FRA, 2010); European Migration Network, Policies on Reception, Return and Integration Arrangements for, and Numbers of, Unaccompanied Minors: An Eu Comparative Study (Brussels: EMN, 2010); European Migration Network, Policies, Practices and Data on Unaccompanied Minors in the EU Member States and Norway: Synthesis Report (Brussels: EMN, 2015); International Organization for Migration, Unaccompanied Minor Asylum-Seekers: Overview of Protection, Assistance and Promising Practices (Budapest: IOM, 2011); UNHCR, Trees Only Move in the Wind: A Study of Unaccompanied Afghan Children in Europe (Geneva: UNHCR, 2010); UNHCR, Protecting Children on the Move (Rome: UNHCR, 2012).

47 The EU Action Plan on Unaccompanied Minors covered the period 2010-14 and has not yet been followed by a similar action plan or policy.

48 Bhabha, "More Than Their Share of Sorrows"; Kate Halvorsen, Asylum Decisions on Child Applicants: Report on 4-Country Pilot Project (Oslo: Norwegian Government, 2004), 40.
49 Eeva Nykänen, "Protecting Children? The European Convention on Human Rights and Child Asylum-seekers," European Journal of Migration and Law 3 (2001): 315-45.

50 European Migration Network, The Different National Practices concerning Granting of Non-EU Harmonised Protection Statuses (Brussels: EMN, 2010); European Migration Network, Policies, Practices and Data on Unaccompanied Minors in the EU Member States and Norway, Synthesis Report (Brussels: EMN, 2015).

51 Greater Manchester Immigration Aid Unit, Child's Best Interests; European Migration Network, Different National Practices.

52 Council of Europe and UNHCR, Unaccompanied and Separated Asylum-Seeking and Refugee Children Turning Eighteen: What to Celebrate? (Strasbourg: Council of Europe, 2014), 10.

53 UNHCR, Guidelines on Child Asylum Claims, para. 7; Council of Europe and UnHCR, What to Celebrate?, 10.

54 European Migration Network, Policies, Practices and Data, 7 and 33 .

55 Hans E. Anderson, Henry Ascher, Ulla Bjornberg, Marita Eastmond, and Lootta Mellander, eds., The AsylumSeeking Child in Europe (Göteborg: Centre for European Research at Göteborg University, 2005); Liden and Rusten, "Asylum, Participation and the Best Interests of the Child," 274.

56 Julia O'Connell-Davidson and Caitlin Farrow, Child Migration and the Construction of Vulnerability (Stockholm: Save the Children Sweden, 2007), 11.

57 Ibid., 44-5.

58 See also European Court of Human Rights Factsheet on Migrants in Detention, July 2014, http://www.echr.coe.int/ Documents/Fs_Migrants_detention_ENG.pdf.

59 Bhabha and Young, "Not Adults in Miniature," 87.

60 UNHCR, Handbook and Guidelines on Procedures and Criteria for Determining Refugee Status under the 1951 Convention and the 1967 Protocol Relating to the Status of Refugees, December 2011, HCR/1P/4/ENG/REV. 3, http://www. refworld.org/docid/4f33c8d92.html, para 213.

61 Bhabha and Young, "Not Adults in Miniature," 113.

62 UNHCR, Handbook and Guidelines on Procedures and Criteria, para. 185 .

63 UNHCR UK, Untold Stories ... Families in the Asylum Process (London: UNHCR UK, 2013); Thomas Berthold, In Erster Linie Kinder: Flüchtlingskinder in Deutschland (Cologne: German Committee for UNICEF, 2014).

64 UNHCR, Handbook and Guidelines on Procedures and Criteria, paras. 213-19; Guy Goodwin-Gill, The Refugee in International Law, 2nd ed. (Oxford: Oxford University Press 1996), 357

65 Goodwin-Gill, Refugee in International Law, 357.

66 Jacqueline Bhabha, "Minors or Aliens? Inconsistent State Intervention and Separated Asylum-Seekers," European Journal of Migration and Law 3 (2001): 283-314.

67 Berthold, In Erster Linie Kinder, 10. 
68 Ibid., 16.

69 Ibid., 21.

70 Ibid.; Verena Knaus and Peter Widmann, Integration Subject to Conditions (Cologne: UnICEF Kosovo and the German Committee for UNICEF, 2010); Verena Knaus, No Place to Call Home: Repatriation from Germany to Kosovo as Seen and Experienced by Roma, Ashkali and Egyptian children (Cologne: UnICEF Kosovo and the German Committee for UNICEF, 2011).

71 UNHCR UK, Untold Stories, 7.

72 Ibid., 20 and 24.

73 Ibid., 40.

74 Ibid., 44 .

75 UNHCR UK, Considering the Best Interests of the Child within a Family Seeking Asylum (London: UNHCR UK, 2013), 7.

76 un Committee on the Rights of the Child, General Comment No. 12 (2009): The Right of the Child to Be Heard, 20 July 2009, CRC/C/GC/12, http://www.refworld.org/ $\mathrm{docid} / 4$ ae $562 \mathrm{c} 52 . \mathrm{html}$.

77 Ibid., 23.

78 Ibid., 29.

79 Ibid., 36 .

80 Committee on the Rights of the Child, General Comment No. 6.

81 UNHCR UK, Considering the Best Interests of the Child, 41.

82 HIT Foundation, Monitoring Returned Minors Final Report (Netherlands: HIT Foundation, 2014), 3.

83 Bridgette A. Carr, "Incorporating a 'Best Interests of the Child' Approach into Immigration Law and Procedure," Yale Human Rights and Development Journal 12, no. 1 (2009): 159; Jennifer Nagda and Maria Woltjen, "Best Interests of the Child Standard: Bringing Common Sense to Immigration Decisions," in Big Ideas Pioneering Change: Innovative Ideas for Children and Families, 105-16 (Washington, DC: First Focus, 2015).

84 Goodwin-Gill, "Unaccompanied Refugee Minors," 410.

85 Committee on the Rights of the Child, General Comment No. 6, para 79.

86 UNHCR and UNICEF, Safe and Sound, 22.

87 UnHCR, OHCHR, UNICEF, UNDOC, un Women, and ILO, Prevent. Combat. Protect: Human Trafficking: Joint un Commentary on the EU Directive-A Human Rights-Based Approach (Brussels: OHCHR, 2011); Council of the European Union, Directive 2011/36/EU of the European Parliament and of the Council of 5 April 2011 on Preventing and Combating Trafficking in Human Beings and Protecting Its Victims, and Replacing Council Framework Decision 2002/629/JHA, 15 April 2011, OJ L. 101/1-101/11; 15.4.2011, 2011/36/EU, http:// www.refworld.org/docid/5oec1e172.html.

88 Council of Europe Convention on Action against Trafficking in Human Beings, 16 May 2005, CETS 197, http://www. refworld.org/docid/43fded544.html, Article 14:2.

89 Nagda and Woltjen, "Best Interests of the Child Standard."
90 Un Committee on the Rights of the Child, General comment No. 14 (2013) on the Right of the Child to Have His or Her Best Interests Taken as a Primary Consideration (Art. 3, Para. 1), 29 May 2013, CRC/C/GC/14, http://www.refworld. org/docid/51a84b5e4.html.

91 Carr, "Incorporating a 'Best Interests of the Child," 127.

92 Jane McAdam, "Seeking Asylum under the Convention on the Rights of the Child: A Case for Complementary Protection," International Journals of Children's Rights 14 (2006): 251.

93 Pobjoy, "Best Interests of the Child Principle," 343.

94 UNICEF and OHCHR, Judicial Implementation of Article 3; Pobjoy, "Best Interests of the Child Principle."

95 Separated Children in Europe Programme, Statement of Good Practice, 4th ed. (Copenhagen: Save the Children, 2009).

96 Smyth, European Asylum Law.

97 Save the Children, CONNECT Project Reference Document on Eu Law and Policy (Stockholm: Save the Children, 2014).

98 UNHCR, Improving Asylum Procedures: Comparative Analysis and Recommendations for Law and Practice, Detailed Research on Key Asylum Procedures Directive Provisions (Brussels: UNHCR, 2010), 24.

99 Committee on the Rights of the Child, un Committee on the Rights of the Child, GeneralComment No.12 (2009): The Right of the Vhild to Be Heard, 20 July 2009, CRC/C/GC/12, http:// www.refworld.org/docid/4ae562c52.html, paras. 20-1; Committee on the Rights of the Child, General Comment No. 6, para. 66 .

100 UNHCR, Guidelines on Child Asylum Claims, para. 71.

101 Swedish Migration Board, Regulation 996, 2007; Swedish Migration Board, Barnets bästa och barnkonsekvensanalys. Checklista för barnkonsekvensanalys barn i familj, 2013; Swedish Migration Board, Ansökningsenhetens checklista inför barnkonsekvensanalys BUV, 2013. Swedish Migration Board, Prövningsenhetens checklista inför barnkonsekvensanalys BUV, 2013.

102 UNICEF Netherlands, “Child Notices," 28 January 2016, http://www.unicef.nl/wat-doet-unicef/ kinderrechten-in-nl/child-notices/english/.

103 Liden and Rusten, "Asylum, Participation and the Best Interests of the Child," 279.

104 Ibid., 280.

105 Lundberg, "Best Interests of the Child," 62.

106 UNHCR, The Heart of the Matter: Assessing Credibility When Children Apply for Asylum in the European Union (Brussels: UNHCR, 2014).

107 Margrite E. Kalverboer, The Best Interests of the Child in Migration Law: Significance and Implications in Terms of Child Development and Child Rearing (Amsterdam: swP Publishers, 2014), 12.

108 UnHCR, Conclusion on Children at Risk, 5 October 2007, No. 107 (LVIII)-2007, http://www.refworld.org/ docid/471897232.html. 
109 European Migration Network. Policies, Practices and Data (Brussels: EMN, 2015), 27.

110 Pobjoy, "Best Interests of the Child Principle."

111 McAdam, "Seeking Asylum under the Convention on the Rights of the Child," 251.

112 Karin Fagerholm and Rhea Verheul, Safety and Fundamental Rights at Stake for Children on the Move (Brussels: European Network of Ombudsmen, 2016).
113 UNHCR, "Policy on Refugee Children," Refugee Survey Quarterly 15, no. 3 (1996): 48-56, para. 24.

114 Berthold, In Erster Linie Kinder, 28.

Jyothi Kanics is a research fellow at the University of Lucerne. The authormaybe contacted at jkanics@hotmail.com. 